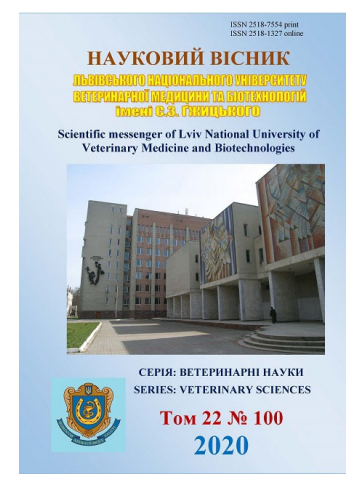

\author{
Науковий вісник Дьвівського національного університету \\ ветеринарної медицини та біотехнологій імені С.3. Гжицького. \\ Серія: Ветеринарні науки
Scientific Messenger of Lviv National University of Veterinary Medicine and Biotechnologies. \\ Series: Veterinary sciences
}

UDC 619. 477

\title{
The treatment of animals in Galicia in the middle ages
}

\author{
V. Prysyazhnyuk \\ Stepan Gzhytskyi National University of Veterinary Medicine and Biotechnologies Lviv, Ukraine
}

Article info

Received 28.09.2020 Received in revised form 29.10.2020 Accepted 30.10.2020

Stepan Gzhytskyi National University of Veterinary Medicine and Biotechnologies Lviv, Pekarska Str., 50, Lviv, 79010, Ukraine. Tel.: +38-097-624-42-08 E-mail:Vasyl.prysyaznyuk@gmail com
Prysyazhnyuk, V. (2020). The treatment of animals in galicia in the middle ages. Scientific Messenger of Lviv National University of Veterinary Medicine and Biotechnologies. Series: Veterinary sciences, 22(100), 32-35. doi: 10.32718/nvlvet10006

Surgical diseases. At head injuries was carried out bloodletting from the jugular vein and infusion into the nasal cavity of chopped horseradish and citrus, mixing with wine, to cause nasal discharge, the outflow of which had a positive influence on the course of the disease. Surgical procedures in the oral cavity of a horse. Sharp teeth are blunted if you insert an iron bar between them. When chewing a bar, the horse must break its sharp ends. Wolf teeth or fangs can be removed with a chisel. The salivary glands under the tongue was called tuberculosis which in some cases were removed surgically. The wounds of the tongue were called "mucus", lubricated with quicklime, mercury, honey. In cases of laminitis, the reasons for which could be wind, rye, water, treatment was based on blood from the jugular vein, tail, cheeks, limbs or from the veins of the palate, with the simultaneous use of herbal remedies such as asparagus, laxatives (cleansers), and bathing the limbs in cold water. When sitting (something like steaming from the saddle) were used wraps with vinegar, clay or washing with the above means. In cases of abdominal edema were used wet and warm compresses using a harness. When the scapula was damaged, a massage with rubbing a mixture of bean oil, turpentine and olive oil was effective. If there were cracks in the bone, the place on the other side of the crack was burned with hot iron, and in addition to wrapping with the roots of plants, leaves and bread, a bandage of thin boards and a bandage was applied. In case of a broken bone - a calm horse was given a permanent bandage and a bandage with pre-lubrication of the limbs with fat. Disease of shuttle bones. Were burned with iron and covered with herbs, or lubricated with ointment, consisting of resin, vegetable oil and bean oil. Phlegmons and congestive edema of the extremities were treated by wrapping a mixture of poppy oil, including bloodletting from this limb, or massage with the simultaneous use of substances such as: nettle root or cumin, ground with honey and flour. Inflammation of the tendons was called a clogged vein, wrapping a mixture of onions and garlic was recommended for medicinal purposes. The pile (lump) "called a dog's hair" has been treated with human feces for two centuries. Dislocations and subdislocations. After directing the bone to the starting position, a mixture of vinegar, honey and tire was used. Rub, peel off the hoof (mutilation of the hoof, resulting from the attack of one limb on the other). After cutting the mutilated (wounded) place and cleaning the wound by rinsing with oil or vinegar it is necessary to cover the damage with melted wax, fat or resin. Cut the damaged horn especially when there is suppuration. When a horseshoe nail is driven deep into the hoof during shoeing, the horseshoe must be removed, open the sole in the area of the disease, and in order to allow the leakage of pus (exudate) to wash the wound with oil. To prevent further contamination of the wound, fill it with resin. Penetration of alien bodies into the hoof from below. This can happen when a horse steps on a sharp object. Were treated as described above. The so-called Spartan shoes were put on the hoof, which is still in common use today. When there was a suspicion that there was exudate in the wall of the hoof, to determine where, you need to moisten the horn of the hoof with water. The place that became dry the fastest due to the rising temperature was the most suitable for opening and the possibility of exudate. The curvature that most often occurs in barefoot unshod horses, the horn was removed with a knife up to the soft tissues of the hoof, the wound was tapenaded by wetting the tampons with vinegar, honey, or impregnate them with salt or lime, it is impossible to use alum in the final period of treatment. Granulation tissue exacerbation was treated with caustic agents such as copper green or ferrous sulfate. Ulcers were opened with steamed iron or accelerated their natural opening with the help of Spanish flies. After opening, they were covered with powdered sulfur or bread with salt. Lubricate the edema with wine yeast or grated burdock root, and knife wounds were tamponade with a saturated mixture of resin, sulfur, vinegar. Bruises on the body of animals were lubricated the damaged areas with ointment from nettle root and fat, and the removal of exterior bodies from gunshot wounds was carried out by induction of wound suppuration with mercury ointment, alkali. Iron particles embedded in the wound, tried to remove with a magnet. Cluster of hair - caused acceleration ointment, consisting of roundworms, bees and oil, and the 
intensive molting was facilitated by smearing the horse's fur with his own blood. White spots, varieties on the corresponding horse hair were treated through burns of this place with hot dough mixed with mustard and strong vinegar. It should be noted that one of the most common surgical procedures was bloodletting and it is from the various veins of the horse's body. Not only for internal or surgical diseases, but also as a means of disease prevention was used. Eye diseases, namely: swollen eyes with flowing tears, under this name should be understood as a series of inflammatory conditions of both eyes and eyelids. Treatment-blood from a vein over the orbits, as well as well-washed eyes with well water. In endosperm, it was recommended to inject powdered substances such as feces, pepper, ginger, feathers, lard, alum into the eye.

Key words: medical business, animals, folk medicine, diseases, medicines.

\title{
Лікувальна справа тварин у Галичині в середні віки
}

\author{
В. Я. Присяжнюк
}

Львівський національний університет ветеринарної медицини та біотехнологій імені С. 3. Гжицького, м. Львів, Україна

Хірургічні захворювання. При травмах голови проводили пускання крові з яремної вени і вливання в носові порожнини подрібненого хрону та циитрусових, змішуючи з вином, щсоб викликати виділення з носа, відтік якого позитивно впливав на перебіг захворювання. Хірургічні процедури в ротовій порожнині коня. Гострі зуби притуплюються, якщо вставити між ними залізний брусок. При жуванні бруска кінь повинен розбити свої гострі кінці. Вовчі зуби або ікла можуть бути видалені долотом. Сухотами називали слинні залози під язиком, які в деяких випадках видаляли хірургічним шляхом. Рани язика називали “слизами”, змащували негашеним вапном, ртуттю, медом. У випадках захворювання на ламініт, причинами якого могли бути вітер, жито, вода лікування базувалося на пусканні крові з яремної вени, хвоста, щік, кінцівок або з вен піднебіння з одночасним використанням рослинних засобів, таких як спаржа, проносних (очищаючих) засобів і купання кінцівок в холодній воді. Якщз були тріщини кістки, то місце з другого боку тріщини обпалювали гарячим залізом, а крім обгортання з корінням рослин, листя і хліба, накладали пов'язку з тонких дошечок $i$ бандажу. У випадку зламу кістки - у спокійного коня накладали постійну пов 'язку з домечок $i$ бандажу з попереднім змащуванням кінцівок жиром. Хвороба човникової кістки. Обпалювали залізом і накривали зеленню або змащували маззю, цо складалася зі смоли, олії рослин та бобового масла. У свіжсих випадках - огоління волосся $і$ енергійний масаж для розсмоктування. Флегмони і застійні набряки кінцівок лікували шляхом обгортання сумішшю з макової олї, включаючи пускання крові з даної кінцівки або масаж з одночасним застосуванням таких речовин, як корінь кропиви або кмин, розтертий з медом і мукою. Запалення сухожиль називали забиттям вени, в лікувальних иүілях рекомендували обгортання сумішшю з цибулі та часнику. Після направлення кістки до початкового положення застосовували обгортання суміштю з оиту, меду і шини. Затерте, здерте копито (скалічення копита, що виникли в результаті наступу однією кінцівкою на іншу). Після вистриження скаліченого (пораненого) місия і очищення рани промиванням олією або оитом необхідно накрити пошкодження розтопленим воском, жиром або смолою. Пошкоджений ріг вирізати, особливо коли є нагноєння. Коли під час підковування підковний ивях забитий заглибоко в копито необхідно видалити підкову, підошву в иій ділянці відкрити, а для того щчоб дозволити витік гною (ексудату), рану промити олією. Щоб запобігти можливому забрудненню рани, залити ї̈ смолою. Проникнення сторонніх тіл в копито знизу. Може ие статися, коли кінь наступить на гострий предмет. Лікування подібне на те, щзо описано вище. На копито накладали так зване спартанське взуття, яке є сьогодні в загальному користуванні. Коли була підозра, щзо в стінці копита є ексудат, щуоб визначити в якому місиі, потрібно ріг копита змочити водою. Місие, яке найшвидше стало сухе внаслідок підвищення температури, було найбільш придатне до відкриття і можливості виходу ексудату назовні. Виразки відкривали розжареним залізом або прискорювали їх природне відкриття за допомогою іспанських мух. Після розкриття покривали їх порошкоподібною сіркою або хлібом з сіллю. Набряки змашувати винними дріжджами або тертим коренем лопуха, а ножові рани тампонували насиченою сумішшю смоли, сірки, оцту. Синяки на тілі тварин - змашували пошкоджені місия маззю з кореня кропиви і жиру, а видалення сторонніх тіл від вогнепальних поранень здійснювалося індукцією нагноєння рани ртутною маззю, лугом. Залізні частинки з рани намагалися витягти за допомогою магніту. Варто зазначити, що однією з найчастіших хірургічних прочедур було пускання крові, і ие з різних вен тіла коня. Застосовували не тільки при внутрішніх хворобах чи хірургічних, а також як засіб профілактики хвороб. Хвороби очей, а саме: опухлі очі зі слізьми, під иією назвою мали на увазі иілу серію запальних станів як ока, так і повік. Лікування - пускання крові з вени над очницями, а також добре промивали очі колодязною водою. При ендоспермі рекомендували вдувати до ока порошкоподібні речовини, такі як кал, перець, імбир, пір'я, сало, галун.

Ключові слова: лікувальна справа, тварини, народна медицина, захворювання, лікарські засоби.

\section{Ветуп}

Впродовж останніх років опубліковано цілу низку наукових досліджень вітчизняних авторів (Воgоjavlenskij, 1980; Verkhratskyi \& Zabludovskyi, 1991; Rudyk \& Bisiuk, 2000; Sadvari et al., 2000; Kurtiak \& Tkachuk, 2001; Verbytskyi et al., 2002; Prysiazhniuk, 2017), присвячених історії медицини, що розкриває питання зародження, становлення та розвитку лікувальної справи, в тому числі у різних регіонах України залежно від політичних i соціально-економічних умов. У деяких наукових працях показано організа- цію і становлення державної ветеринарної служби певного краю, області (Rudyk \& Bisiuk, 2000; Verbytskyi et al., 2002) і України загалом.

Мета дослідження: висвітлити питання діяльності фахівців лікувальної справи тварин в середні віки 3 метою недопущення захворювань та лікування тварин в певних історичних умовах в Галичині.

Завдання дослідження полягали в тому, щоб отримати дані щодо організації форм роботи фахівців лікувальної справи тварин в середні віки в Україні, зокрема в Галичині, використання ними різноманітних лікувальних засобів рослинного, тваринного та 
мінерального походження при лікуванні різних захворювань тварин, розкрити сутність народної ветеринаpiï, діяльність народних цілителів з метою зменшення захворюваності тварин і людей у певних політичних та соціально-економічних умовах.

\section{Матеріал і методи досліджень}

Матеріалом для вивчення лікувальної справи тварин на західноукраїнських землях в середні віки були окремі архівні документи державного історичного архіву м. Львова, періодичні видання, статті, а також деякі вітчизняні та іноземні бібліографічні джерела Національної наукової бібліотеки імені В. Стефаника НАН України у м. Львові. При проведенні досліджень використано методи: хронологічний, системний, порівняльно-історичний, аналітичний.

\section{Результати та їх обговорення}

У зв'язку з масовими захворюваннями тварин, зокрема коней, вже у XV столітті описані фахівці лікувальної справи тварин, так звані “коневые лекари” і кровопускні. Таким чином в цей час фахівці лікувальної справи тварин виокремили особливу професію ветеринарний лікар, яка має давнє історичне коріння і джерела розвитку. Починаючи з середніх віків, лікуванням тварин все частіше почали займатися конюхи, пастухи, народні цілителі, знахарі. 3 розвитком тваринницьких господарств власники тварин та члени їхніх сімей виступають в ролі одночасно і пастухів, $\mathrm{i}$ ветеринарів - фахівців лікувальної справи, які вміли допомагати при незначних пошкодженнях і хворобах тварин. Господарі та доглядачі тварин вміли стежити за їхнім здоров'ям, визначати деякі хвороби і надавати тваринам посильну лікувальну допомогу. Господаpi, пастухи, конюхи, народні цілителі, знахарі добре усвідомлювали, що з метою профілактики захворювань тварин потрібно утримувати в чистоті, добре годувати, випасати лише на сухих пасовищах.

Для фахівців лікувальної справи були видані лікувальники, в яких поряд з питаннями, що стосувалися лікування людей, були настанови і низка порад щодо лікування тварин. Окремо були створені лікувальні конюшні, де ізолювали і лікували хворих коней. 3 1626 року ветеринарних спеціалістів при великих конюшнях називали “коновалами".

У народній лікувальній справі тварин застосовували в основному ті ж засоби, що і в народній медицині. Так, при розладах травлення у тварин ї напували відварами звіробою, дубової кори, деревію, кмину, а у випадках розладів шлунка давали пити відвар з насіння льону. Незначні рани у тварин лікували соком або товченим листям ранника, промивали рани відварами ромашки, чебрецю, живокосту. Шкірні захворювання та різні висипки народні цілителі лікували водяним відваром тютюну, гірчака, а також домашнім квасом та дьогтем. Відвар живокосту використовували для змащування хворого вимені худоби. При здутті худоби від перегодовування іï напували огірковим розчином або олією, також закріплювали в роті дерев'яну палицю з фруктових дерев або солом'яне перевесло та проганяли до сильного спітніння.

Часто рослинні лікувальні засоби застосовувалися у поєднанні 3 тваринними жирами, мінеральними речовинами. Для пониження температури тіла тварин змащували розчином рудої глини, буряковим квасом. Синій камінь (мідний купорос) застосовували при лікуванні тварин, хворих на ящур. Домашній квас, змішаний із селітрою та нашатирним спиртом, використовували для лікування тварин від сибірської виразки. Відвар на буряковому квасі насіння конопель, льону, інших зернових із додаванням заліза, мідного купоросу, дьогтю, часнику використовували при лікуванні тварин, хворих на чуму. Часто при багатьох захворюваннях тварин проводили кровопускання.

Хірургічні захворювання. При травмах голови проводили пускання крові з яремної вени і вливання в носові порожнини подрібненого хрону і цитрусових, змішуючи з вином, щоб викликати виділення з носа, відтік якого позитивно впливав на перебіг захворювання. Хірургічні процедури в ротовій порожнині коня. Гострі зуби притуплюються, якщо вставити між ними залізний брусок. При жуванні бруска кінь повинен розбити свої гострі кінці. Вовчі зуби або ікла можуть бути видалені долотом. Сухотами називали слинні залози під язиком, які в деяких випадках видаляли хірургічним шляхом. Рани язика називали “слизами”, змащували негашеним вапном, ртуттю, медом.

У випадках захворювання на ламініт, причинами якого могли бути вітер, жито, вода, лікування базувалося на пусканні крові з яремної вени, хвоста, щік, кінцівок або з вен піднебіння, з одночасним використанням рослинних засобів, таких як спаржа, проносних (очищаючих) засобів і купання кінцівок в холодній воді.

При відсиджуванні (подібне на запарювання від сідла) застосовували обгортання з оцтом, глиною або промивання вищезазначеними засобами. У випадках захворювання на абдомінальний набряк живота використовували мокрі й теплі компреси за допомогою упряжі. При пошкодженнях лопатки ефективним був масаж з втиранням суміші з бобового масла, скипидару і оливкової олії.

Якщо були тріщини кістки, то місце з другого боку тріщини обпалювали гарячим залізом, а крім обгортання 3 корінням рослин, листя і хліба, накладали пов'язку з тонких дощечок і бандажу. У випадку зламу кістки - у спокійного коня накладали постійну пов'язку з дощечок і бандажу з попереднім змащуванням кінцівок жиром.

Хвороба човникової кістки. Обпалювали залізом і накривали зеленню або змащували маззю, що складалася зі смоли, олії рослин та бобового масла. У свіжих випадках - огоління волосся і енергійний масаж для розсмоктування.

Флегмони i застійні набряки кінцівок лікували шляхом обгортання сумішшю з макової олії, включаючи пускання крові 3 даної кінцівки або масаж $з$ одночасним застосуванням таких речовин, як корінь кропиви або кмин, розтертий з медом і мукою. Запалення сухожиль називали забиттям вени, в лікуваль- 
них цілях рекомендували обгортання сумішшю з цибулі та часнику. Груду (грудку), що називається “собачим волоссям", протягом двох століть лікували людським калом. Вивихи і підвивихи. Після направлення кістки до початкового положення застосовували обгортання сумішшю з оцту, меду і шини.

Затерте, здерте копито (скалічення копита, що виникли в результаті наступу однією кінцівкою на другу). Після вистриження скаліченого (пораненого) місця і очищення рани промиванням олією або оцтом необхідно накрити пошкодження розтопленим воском, жиром або смолою. Пошкоджений ріг вирізати, особливо коли $є$ нагноєння. Коли під час підковування підковний цвях забитий заглибоко в копито, необхідно видалити підкову, підошву в цій ділянці відкрити, а для того, щоб дозволити витік гною (ексудату), рану промити олією. Щоб запобігти можливому забрудненню рани - залити їі смолою.

Проникнення сторонніх тіл в копито знизу. Може це статися, коли кінь наступить на гострий предмет. Лікування подібне на те, що описано вище. На копито накладали так зване спартанське взуття, яке $є$ і сьогодні в загальному користуванні. Коли була підозра, що в стінці копита $\epsilon$ ексудат, щоб визначити, в якому місці, потрібно ріг копита змочити водою. Місце, яке найшвидше стало сухе внаслідок підвищення температури, було найбільш придатне до відкриття і можливості виходу ексудату назовні.

Виразки відкривали розжареним залізом або прискорювали їх природне відкриття за допомогою іспанських мух. Після розкриття покривали їх порошкоподібною сіркою або хлібом з сіллю. Набряки змащувати винними дріжджами або тертим коренем лопуха, а ножові рани тампонували насиченою сумішшю смоли, сірки, оцту.

Синяки на тілі тварин - змащували пошкоджені місця маззю $з$ кореня кропиви і жиру, а видалення сторонніх тіл від вогнепальних поранень здійснювалося індукцією нагноєння рани ртутною маззю, лугом. Залізні частинки з рани намагалися витягти за допомогою магніту.

Прискорювала ріст волосся мазь, що складалася 3 круглих черв'яків, бджіл і масла, а інтенсивній линьці сприяло намазування шерсті коня його власною кров’ю. Білі плями, різновиди на відповідній шерсті коня лікували через опік даного місця гарячим тістом, змішаним з гірчицею і міцним оцтом.

Варто зазначити, що однією $з$ найчастіших хірургічних процедур було пускання крові, і це з різних вен тіла коня. Застосовували не тільки при внутрішніх хворобах чи хірургічних, а також як засіб профілактики хвороб.

Хвороби очей, а саме: опухлі очі зі слізьми, під цією назвою мали на увазі цілу серію запальних станів як ока, так і повік. Лікування - пускання крові з вени над очницями, а також добре промивали очі колодязною водою. При ендоспермі рекомендували вдувати до ока порошкоподібні речовини, такі як кал, перець, імбир, пір'я, сало, галун.

\section{Висновки}

Першими фахівцями лікувальної справи тварин у середні віки в Галичині були пастухи, скотарі, вівчарі, конюхи, народні цілителі, знахарі, власники тварин.

Фахівці народної ветеринарної медицини розробили санітарно-гігієнічні заходи, спрямовані на відвернення появи і поширення заразних захворювань тварин і людей.

Для лікування тварин використовували засоби рослинного, тваринного i мінерального походження, часто - у різному поєднанні цих засобів.

Перспективи подальших досліджень. Планується дослідити діяльність ветеринарних фахівців щодо організації санітарно-карантинних, гігієнічних заходів при захворюваннях тварин та їхню роль в розвитку лікувальної справи і тваринництва в Галичині.

\section{References}

Aranchii, S. V. (1998). Istoriia veterynarnoi medytsyny Poltavshchyny. Poltava: Poltavskyi literator (in Ukrainian).

Bogojavlenskij, N. A. (1980). Drevnerusskoe vrachevanie v H1-HUIIst. M. (in Russian).

Kasova knyha tsekhu kovaliv. TsDIA m. Lvova. F. 52, O. 2, S. 996-999 (in Ukrainian).

Knyha zapysiv protokoliv vyzvolennia tsekhu kovaliv. TsDIA m. Lvova. F. 52, O. 2, 989-995 (in Ukrainian).

Kodeks pryvileiv i prav $\mathrm{m}$. Lvova za 1356-1685rr. Ukladach Antonii Alembek. TsDIA m. Lvova. F. 52, O. 2, 1153 (in Ukrainian).

Kurtiak, B. M., \& Tkachuk, P. S. (2001). Narys istorii veterynarnoi medytsyny Lvivshchyny. Lviv: Triada plius (in Ukrainian).

Prysiazhniuk, V. Ia. (2017). Parostky likuvalnoi spravy tvaryn v Halychyni. Naukovyi visnyk Lvivskoho natsionalnoho universytetu veterynarnoi medytsyny ta biotekhnolohii imeni S. Z. Gzhytskoho. Seriia: Veterynarni nauky, 19(77), 158-161. URL: http://nbuv.gov.ua/UJRN/nvlnuvmbvn_2017_19_77_3 6 (in Ukrainian).

Rudyk, S. K., \& Bisiuk, I. Iu. (2000). Istoriia veterynarnoi medytsyny Kyivshchyny. K. Ahrosvit (in Ukrainian).

Sadvari, Yu. Iu., Bakhtyn, V. F., \& Dudash, A. V. (2000). Veterynarna medytsyna Zakarpattia na mezhi tysiacholit. Uzhhorod: Patent (in Ukrainian).

Tsentralnyi derzhavnyi istorychnyi arkhiv Ukrainy u $\mathrm{m}$. Lvovi (TsDIA), Fond 52, Opys 2, Sprava 8 (in Ukrainian).

Verbytskyi, P. I., Dostoievskyi, P. P., \& Rudyk, S. K. (2002). Istoriia veterynarnoi medytsyny Ukrainy. K. Vetinform (in Ukrainian).

Verkhratskyi, S. A., \& Zabludovskyi, P. Iu. (1991). Istoriia medytsyny. Kyiv (in Ukrainian).

Vytiahy z Lvivskykh zemskykh i miskykh aktiv u spravakh mista za 1411-1786 rr. TsDIA m. Lvova. F. 52, O. 2, 644 (in Ukrainian). 